\title{
Elektronik Müşteri İlişkileri Uygulamalarının Algılanan İlişki Kalitesi ve Müşteri Sadakati Üzerine Etkisi: Havayolu Sektöründe Bir Araştırma \\ (The Influence of Electronic Customer Relationship Management Practices on Relationship Quality and Customer Loyalty: A Research in Airline Industry)
}

\author{
Alev SÖKMEN IDa Mehmet BAŞ \\ a Başkent Üniversitesi Sosyal Bilimler Meslek Yüksekokulu, Ankara, Türkiye. alev@baskent.edu.tr \\ b Ankara Hacı Bayram Veli Üniversitesi, İktisadi ve İdari Bilimler Fakültesi, , Ankara, Türkiye. mehmet.bas@hbv.edu.tr
}

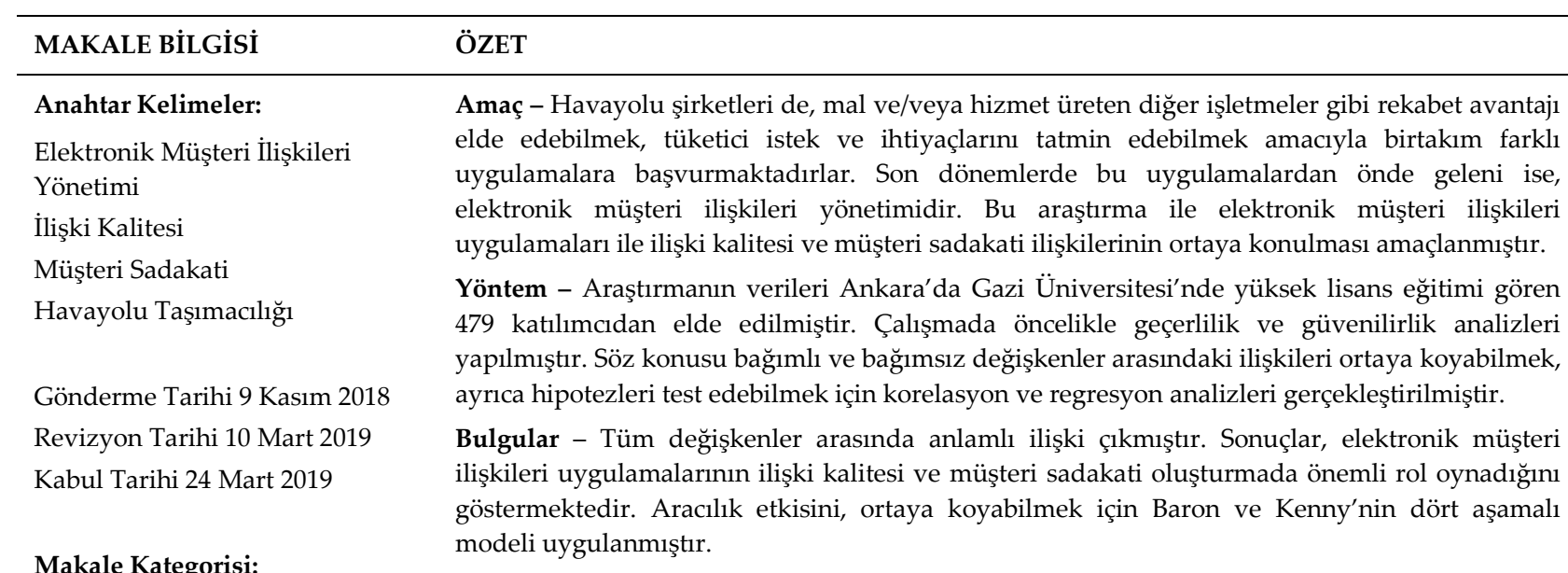

Makale Kategorisi:

Araştırma Makalesi

Tartışma - Elde edilen bulgulardan ilişki kalitesinin elektronik müşteri ilişkileri uygulamalarının müşteri sadakatine etkisinde aracılık rolü oynadığı da tespit edilmiştir.

\begin{tabular}{|c|c|}
\hline ARTICLE INFO & ABSTRACT \\
\hline $\begin{array}{l}\text { Keywords: } \\
\text { Electronic Customer Relationship } \\
\text { Management } \\
\text { Relationship Quality }\end{array}$ & $\begin{array}{l}\text { Purpose - Like other companies, airline carriers search for several strategies in order to gain } \\
\text { competitive advantage and satisfy consumers' needs and wants. In recent years, one of the } \\
\text { leading practices is electronic customer relation management. This research investigates the } \\
\text { relationship between electronic customer relationship management practices, relationship } \\
\text { quality, and customer loyalty. }\end{array}$ \\
\hline $\begin{array}{l}\text { Customer Loyalty } \\
\text { Airline Industry }\end{array}$ & $\begin{array}{l}\text { Design/methodology/approach - A quantitative research was employed on } 479 \text { postgraduate } \\
\text { students in Gazi University. The reliability and validity of the measurement instrument are } \\
\text { tested before. Correlation and series of regression analyses are applied for investigating } \\
\text { relationships and testing research hypotheses. }\end{array}$ \\
\hline $\begin{array}{l}\text { Revised } 10 \text { March } 2019 \\
\text { Accepted } 24 \text { March } 2019\end{array}$ & $\begin{array}{l}\text { Findings - The results reveal that, positive and significant relationships were found between all } \\
\text { dependent and independent variables. Results also reveal that, electronic customer relationship } \\
\text { practices play important roles in building relationship quality and customer loyalty. Baron and } \\
\text { Kenny's four step procedures are employed in order to test mediation effect. }\end{array}$ \\
\hline $\begin{array}{l}\text { Article Classification: } \\
\text { Research Article }\end{array}$ & $\begin{array}{l}\text { Discussion - Results show that the mediating role of relationship quality in the relationships } \\
\text { between electronic customer relationship management practices and customer loyalty is } \\
\text { supported. }\end{array}$ \\
\hline
\end{tabular}




\section{Giriș}

Günümüzde işletmeler ilişkisel pazarlama stratejilerini destekleyen müşteri hizmetlerini giderek daha yüksek bir oranda yeni teknolojinin yarattığı e-hizmetlerle yerine getirmeye başlamışlardır (Taylor ve Hunter, 2002). Özellikle yoğun rekabetin yaşandığı pazarlarda işletmeler, elektronik müşteri ilişkileri uygulamalarıyla fark yaratarak müşteri sadakati sağlama konusunda çaba sarf etmektedirler. İşletmeler MiY ile insan, süreç ve teknoloji birleşimini sağlayarak müşterilerini anlamaya çalışmaktadırlar (Mandina, 2014). MiY bir işletmenin doğru malı veya hizmeti doğru müşteriye, doğru zamanda, doğru kanaldan, doğru fiyattan ulaştırmak koşuluyla giderek artan seviyede sadık ve kârlı müşterileri belirleme, nitelendirme, kazanma, geliştirme ve elde tutma yolunda gerçekleştirdiği tüm faaliyetlerdir. E-MIY ise internetin devrim yaratan avantajlarını klasik MiY teknikleri ve yeni elektronik kanallarla (web, kablosuz internet, sesli teknolojiler gibi) bütünleştirerek bunları işletmenin genel MiYY stratejileriyle uyumlaştırmaktadır (Fairhurst, 2001; Pan ve Lee, 2003; Maged ve Sarmad, 2004). Bu uygulamalardaki temel amaç teknolojinin avantajlarını kullanarak, müşteriler ile yeni etkileşim alanları oluşturarak onlar ile kurulan ilişki kalitesini artırmak, böylece müşteri sadakati oluşturulmasını sağlamak ve nihai olarak pazarda rekabet avantajı oluşturmaktır.

Müşterilerin işletmeden mal veya hizmet satın almaktan vazgeçme nedenleri araştırıldığında temel sebeplerden birisinin iletişimin kurulduğu temas noktalarının tatmin edici olmaması olduğu görülmektedir. Genelde temas noktalarının sebep olduğu eksikliklerden dolayı müşteriler herhangi bir zaman ihtiyaç duydukları bilgiyi almak için telefon, faks, elektronik veri değişim araçlarını kullanarak iletişim kurmakta ve o anda bu noktalarda çalışan personelin hızı, etkili, net ve tatmin edici hizmeti sunabilmeleri büyük önem taşımaktadır. Ancak bu hizmet bazen personelin yeterli nitelik ve niceliğe sahip olmamasından, gerekli teknolojik araçlarının eksikliğinden ya da her ikisinin de yanlış yönetiminden dolayı görülememektedir (Ryals ve Knox, 2001). Bu bilgiler ışığında araştırmada belirlenen temel amaç, elektronik müşteri ilişkileri uygulamaları (ayrıcalıklı işlem ve ödüller) ile ilişki kalitesi ve müşteri sadakati değişkenleri arasındaki ilişkileri aracılık etkilerini de içerecek şekilde ortaya koymaktır. Bu kapsamda çalışmada öncelikle elektronik müşteri ilişkileri yönetimi, ilişki kalitesi ve müşteri sadakati ele alınmıştır. Son kısımda ise, Gazi Üniversitesi Enstitülerinde öğrenim gören öğrencilerin bir kısmının katılımıyla gerçekleşen araştırmadan elde edilen bulgulara yer verilerek paylaşılmıştır.

\section{Kavramsal Çerçeve}

\subsection{Elektronik Müşteri İlişkileri}

Müşteri İlişkileri Yönetiminin (MIY) temeli 1990’lı yıllarda satış otomasyonu teknolojisi ve çağrı merkezlerindeki faaliyetlere dayanmaktadır. Satış sahasındaki müşteri bilgisi ile çağrı merkezinden elde edilen bilgilerin ortak bir veri tabanında bir araya getirilmesiyle birlikte müşterilerle daha sağlam ilişkilerin kurulabileceği düşüncesiyle oluşmuş MiY kavramı birçok yazar tarafından çeşitli şekillerde tanımlanmaktadır (Osarenkhoe ve Bennani, 2007:145). MiY, yönetim biçiminin müşteri odaklı hâle gelmesidir ve örgütsel faaliyetlerin yeniden tasarlanmasını gerektirir. Buradaki amaç büyüyen ve işletmeye değer katan müşterilerle ilişkileri korumak ve geliştirmektir. Çünkü müşteri işletme için en değerli varlıktır. MIY bu varlıklar üzerinden en yüksek getiriyi elde etmek için kullanılan tekniklerin tümüdür (Hendricks vd., 2007).

Fakat günümüzde işletmeler ilişkisel pazarlama stratejilerini destekleyen müşteri hizmetlerini giderek daha yüksek bir oranda yeni teknolojinin yarattığı e-hizmetlerle yerine getirmeye başlamışlardır (Taylor ve Hunter, 2002). Bir örgüt insan-yoğun hâlinden telefon, fax, e-mail ve web gibi çoklu elektronik temas noktalarına odaklanan bir yapıya bürünmeye başladığında yapıyı geliştirme, yönetme ve ölçme bağlamında müşteri ilişkileri önemli ölçüde artış gösterecektir. Sonuç olarak işletmeler çevrim dışı Mì'den elektronik kanallara yönelmektedirler. Bu yaklaşım genellikle Elektronik Müşteri İlişkileri Yönetimi olarak ifade edilmektedir (Sivaraks vd., 2011). Madeja ve Schoder'e (2003) göre E-MIY müşterilerden daha fazla gelir elde ederek kâr artışı sağlamayı amaçlayan bir e-ticaret uygulamasıdır. Fleischer (2001) ise E-MiY'i, MIYY stratejisinin ve onun uygulamaya geçirilmesinin bir bölümü olarak ifade etmiştir. Müşteri odaklılık ve web tabanlılık E-MIY'in unsurları arasında gösterilmektedir. Web ortamının müşterilerle ilişki kurmak ve onların memnuniyetlerini arttırmak açısından etkili bir ortam olduğu kabul edilmektedir. Web, işletmelerin sunmuş oldukları mal ve hizmetlere müşterilerin göstermiş oldukları tepkilerin tutarlı ve geçerli bir şekilde belirlenmesini, onlarla hızlı bağlantı ya da ilişki kurulmasını sağlamaktadır (Yoon vd., 2008). E-MIY'nin özelliklerini Khalifa ve Shen (2005) satış öncesi, satış esnası ve satış sonrası; Ross (2005) pazarlama, satış ve 


\section{A. Sökmen - M. Baş 11/1 (2019) 641-652}

hizmet; Sterne (1996) ise satış öncesi bilgi, e-ticaret hizmetleri ve satış sonrası destek olmak üzere sinıflandırmışlardır. Lam, Cheung ve Lau (2013) ise E-MİY uygulamalarını; algılanan ödüller (işletmenin müşterilerine sunduğu özel indirimler, kuponlar ve avantajlardır), ayrıcalıklı işlem (işletmenin, sıklıkla alışveriş yapan, bir başka deyişle kar potansiyeli yüksek müşterilerin diğerlerinden ayırarak; onlara özel kişiselleştirilmiş hizmet ve işlem seçeneklerinin sunulması), kişilerarası iletişim (müşterilerin satın almayı düşündükleri ürün ile ilgili olarak detaylı bilgi edinmelerini veya sorularına cevap alabilmelerini sağlayacak müşteri destek hatları, çevrimiçi müşteri hizmetleri vb. ile ilgilidir) ve doğrudan posta (müşterileri özel indirimlerden ve avantajlardan haberdar etmek aynı zamanda yapılan alışveriş ile ilgili fatura, kargo takip gibi tüm süreçler ile ilgili olarak bilgilendirilmesi işlemlerini kapsar) olarak ifade etmiştir.

Temel olarak bütün E-MIY uygulamalarının işletmelere belli açılardan değer sağlama potansiyeli bulunmaktadır (Adabanjo, 2003). E-MIYY uygulamaları sayesinde hizmetler günün 24 saatine ve yılın 365 gününe yayılarak hem müşteri ihtiyaçlarına sürekli şekilde cevap verilebilmekte, hem de hizmet sunumuyla ilgili maliyetlerde önemli tasarruf sağlanmaktadır (Feinberg vd., 2002). Elektronik müşteri hizmetleri ile müşteri ilişkilerini artıran işletmeler müşterilerinin isteklerine optimum seviyede cevap verebilmekte ve sadakatlerini yükseltebilmektedirler. Bu da işletmelerin etkinliğini ve kârlılı̆̆ını artırmaktadır (Khalifa ve Shen, 2005). Elektronik müşteri hizmetlerinin işletmelere sağladığı başlıca faydaların işletme içinde ve tedarik zinciri dâhilinde etkinlik artı̧̧ı, müşteri beklentilerine yönelik gerçeğe en uygun bilgi elde etme ve üretim sürecinde yer alan finansal kaynak kullanımındaki azalmalar olduğu ifade edilebilir. Bu şekilde maliyetlerini aza indirgeyebilen işletmeler sürdürülebilir rekabet avantajı elde etmektedirler.

\section{2. İlişki Kalitesi}

İlişki, "iki ya da daha fazla tarafın ortak bir bilgi platformu oluşturmak amacıyla, birlikte düşünüp muhakeme yaptıkları bir süreç" olarak tanımlanmaktadır (Grönroos, 2000: 5). Dwyer, Shur ve Oh (1987: 15) ilişki sürecinin beş aşamadan oluştuğunu ve bu aşamaların şu şekilde sıralanabileceğini ifade etmektedir: farkında olma, araştırma on), genişleme, bağlılık ve bozulma. İlişki kalitesi kavramı sosyal bilimlerin birçok alanında karşılaşıldığı gibi farklı şekillerde tanımlanabilmektedir. Örneğin bir çalışmada ilişki kalitesi "tüketicinin satıcı ile olan ilişkisinin beklentilerini, tahminlerini, amaçlarını ve isteklerini ne ölçüde karşıladığına yönelik algı" olarak tanımlanmıştır (Oly Ndubisi, 2007: 832). Pazarlama bakış açısıyla ilişki kalitesi ise "alıcı ve satıcı arasındaki ilişkinin bir değerlendirmesi" olarak tanımlanabilir (Čater ve Čater, 2010: 1323). Bu ilişki, nihai tüketici ile satıı arasında oluşabileceği gibi, alıcı ve tedarikçi firmalar arasında da oluşabilir. Illişki kalitesi, nihai tüketici ve satıcı arasında incelendiğinde; hizmet çalışanlarının saygı, nezaket, samimiyet, duygudaşlık (empati) ve yardımseverlik gibi davranışlarının müşteri tarafından algılanması ve değerlendirilmesini ifade etmektedir (King ve Garey, 1997). Levitt (1986) ise ilişki kalitesini "mal ve hizmet sunumlarını genişleten ve alıcı ile satıcı arasında beklenen bir değişim ile sonuçlanan soyut değerler bütünü" olarak tanımlamaktadır (Oly Ndubisi, 2007).

İlgili literatür incelendiğinde ilişki kalitesinin genel olarak dört boyuttan oluştuğunu söylemek mümkündür. Bunlar: İlişki tatmini; alıcının, satıcıyla arasında gerçekleşen hem geçmişteki performansını, hem de ilişki sürecinin tamamını kapsayan deneyimini duygusal ve bilişsel olarak bütüncül bir şekilde değerlendirmesidir (Lages vd., 2005), güven; bir tarafın ihtiyaçlarının gelecekte diğer tarafın sergilediği hareketler vasıtasıyla tam olarak karşılanacağına olan inancı (Morgan ve Hunt, 1994: 23), bağlllık; uzun süreli ve kaliteli ilişkiler için önemli bir diğer boyuttur ve tarafların birbirine ilişkisel anlamda bağımlılıklarının en üst düzeydeki göstergesi olarak tanımlanmaktadır (Dwyer vd., 1987; Gundlach, Achrol ve Mentzer, 1995) ve son olarak iletişim; katılanların, bilgi/sembol üreterek birbirlerine ilettikleri ve bu iletileri anlamaya, yorumlamaya çalıştıkları bir süreç (Dökmen, 1994: 321) olarak ifade edilebilir.

\subsection{Müşteri Sadakati}

Müşteriler, bilânçolarında yer almasa da işletmelerin sahip oldukları en değerli varlıklardır (Parasuraman vd., 1991). Müşteri, sadece işletmenin ürettiği mal ve hizmetleri satın alan değil, aynı zamanda üretilen mal ve hizmetlerden etkilenen herkesi kapsamaktadır. Başka bir deyişle işletmenin herhangi bir bölümünün çıktılarını kullananlar veya bu çıktıların alıcıları da birer müşteridir (Sprague vd., 1992:57). Müşteri, üretim hattının en önemli parçasıdır (Deming, 1996:143). Günümüzde artık müşterilerin istek ve beklentilerinin belirlenmesi ve ona göre ürün ve hizmet üretmek, böylece müşteri memnuniyetinin sağlanması ve sadık müşteriler oluşturulması işletmelerin en önemli öncelikleri arasında yer almaktadır. 


\section{A. Sökmen - M. Baş 11/1 (2019) 641-652}

Zeithaml vd. (1996) sadakati çok yönlü bir kavram olarak tanımlamaktadırlar. Onlara göre "sadakat müşterinin bir işletmeyi başka bir işletme yerine tercih etme, ayn hizmet sağlayıcıdan hizmet satın almaya devam etme ya da hizmet sağlayıcıyla olan iş ilişkisini artırmasıdır". Günümüzün en iyi yöneticileri artık müşterileri ile uzun dönemli ilişkiler kurabilmek için işletme stratejileri içinde müşteri sadakatinin olması gerektiğinin önemini anlamışlardır (Chen vd., 2009). Çünkü müşteri sadakatinin artması finansal gelirlerde artış, düşük müşteri maliyeti ve sonuçta daha fazla kar beklentisi oluşturmaktadır (Chao, 2008). Müşteri sadakatinin oluşmasını belirleyen faktörleri ise; müşteri memnuniyeti, hizmet kalitesi, kurum imajı ve değiştirme maliyeti olarak sıralamak mümkündür.

Sadakatin derecesi her müşteri için aynı değildir. Bunun nedeni müşteri sadakatinin bir süreç olmasıdır. Her müşteri de, bu sürecin farklı bir aşamasında olabilir (Knox, 1998). Bu süreci davranışsal ve tutumsal olarak sınıflandırmak mümkündür. Tucker (1964) müşterinin ne düşündügü ya da kafasında hangi fikirlerin olduğu dikkate alınmadan davranışlarının sadakati tanımladığını ifade etmektedir. Davranışsal sadakat bir müşterinin yeniden satın alma davranışı ya da markaya karşı yoğun ilgisidir (Cheng, 2011). Tutumsal yaklaşım ise müşterilerin psikolojik olarak işletmenin ürün ve hizmetlerine bağlı olmaları şeklinde tanımlanabilir. Eğer bir müşteri tutumsal sadakat ile işletmeye bağlı ise, işletmeden düzenli alışveriş yapmasa bile işletme ve ürünlerini çevresine tavsiye edebilir (Bowen ve Chen, 2001).

Dick ve Basu (1994) tutumsal ve davranışsal sadakat kavramlarını inceleyerek müşteri sadakati kavramının daha iyi anlaşılmasına katkı sağlamışlardır. Bu doğrultuda yazarlar göreli tutum ve tekrarlanan müşteri olma (satın alma) kavramlarını çapraz sınıflama yaparak müşteri sadakati düzeylerini: sadakatsizlik (göreli tutumun ve yeniden müşteri olma ihtimalinin düşük olduğu durumları ifade eder), sahte sadakat (işletmenin sunduğu mal ve hizmetlerin alternatifinin yokluğu sebebiyle seçim şansı olmayan müşterilerde oluşabilmektedir), gizli sadakat (yeniden satın alma davranışı yaratmak için kişisel ölçüler ve sosyal etkiler gibi tutumsal etkenlerin nispeten zayıf kaldığı bir pazar ortamında gerçekleştiği öngörülmektedir) ve gerçek sadakat (müşterilerin gerek işletmenin mal ve hizmetlerini satın almaları ve çevrelerine tavsiye etmeleri gerekse de diğer işletmelerin sunduğu mal ve hizmetlere karşı direnç göstermeleri durumu) olarak tanımlamışlardır.

\subsection{Elektronik Müşteri İlişkileri Yönetimi, İlişki Kalitesi ve Müşteri Sadakati Üzerine Araştırmalar}

Teknolojinin, insan hayatının her anına nüfuz ettiği günümüzde işletmelerin rakipleri karşısında üstünlük sağlayabilmeleri adına örgüt içi uygulamaların yanı sıra müşterileri çekmek, korumak ve ilişkileri derinleştirmek için teknolojiyi en etkin bir şekilde kullanmaları gerektiği yadsınamaz bir gerçektir. Öyle ki; Sivaraks, Krairit ve Tang (2011) tarafından, Tayland'da bir kamu bankasının 684 müşterisinin katılımıyla gerçekleştirilen, araştırmada E-MiY uygulamalarının müşterilerin analiz edilebilmesinde, müşterilere kolaylık sağlanmasında ve müşteri ile olan iletişim kanallarının geliştirilmesinde, ayrıca ilişki kalitesi açısından müşterilerde güven, tatmin, bağlılık, sadakat ve başkalarına tavsiye etme isteği oluşturmasında etkili olduğu tespit edilmiştir. Chung ve Shin (2010) ise internet üzerinden alışveriş yapan web sitesi kullanıcılarına yönelik ortaya koydukları çalışma ile E-MiYY uygulamaların ilişki kalitesi ve ağızdan ağıza pazarlama üzerine etkilerini incelemişlerdir. Araştırma internet üzerinden alışveriş yapan 215 üniversite öğrencisinin katılımıyla gerçekleştirilmiştir. Araştırmada; alışverişe ikna, site dizaynı, bilgilendirme, güvenlik ve iletişim gibi E-MIY uygulamaları ele alınmıştır. Ulaşılan sonuçlara göre bahsi geçen uygulamaların müşteri tatminini pozitif yönde etkilediği, müşteri tatminin de güven ve bağlllık gibi ilişki kalitesi faktörleri üzerinde pozitif yönde etkiye sahip olduğu tespit edilmiştir.

Rafiq, Fulford ve Lu (2013) Tesco, Asda, Sainsbury, Waitrose, Ocado, Foodferr gibi internet üzerinden market ürünleri satışı yapan e-ticaret sitelerinin 491 müşterinin katılımıyla gerçekleştirdikleri araştırmalarında ilişki kalitesinin müşteri sadakati üzerine etkisini incelemişledir. Bu çalışmada ilişki kalitesi; e-ilişki tatmini, e-güven ve e-duygusal bağlllık olmak üzere üç alt boyut ile ele alınmıştır. Elde edilen bulgulara göre e-ilişki kalitesinin e-müşteri sadakatini pozitif yönde etkilediği tespit edilmiştir. Macintosh (2007) tarafından yapılan bir araştırmada ise müşteri odaklılığının ve ilişki kalitesinin işletmeye olan faydaları araştırılmıştır. Araştırmanın örneklemini Kanada'da bulunan bir üniversitenin son 3 yılında acenteler vasıtasıyla seyahat eden 220 personeli oluşturmaktadır. Analiz sonuçlarına göre müşteri odaklılı̆̆ı ve uzmanlık, ilişki kalitesi ile pozitif yönlü anlamlı ilişkiye sahipken ilişki kalitesinin; müşteri sadakati, tatmin ve ağızdan ağıza pazarlamayı pozitif yönde anlamlı bir şekilde etkilediği tespit edilmiştir. 


\section{A. Sökmen - M. Baş 11/1 (2019) 641-652}

Verhoef (2003) Hollandalı bir finans şirketinin iki farklı zamanda 1677 ( $\left.\mathrm{t}_{0}\right)$ ve $918\left(\mathrm{t}_{1}\right)$ müşterisine bir anket çalışması yapmışır. Bu çalışmada müşteri ilişki algılarının ve ilişkisel pazarlama araçlarının müşteriyi elde tutma ve zamanla müşteri payı gelişimi üzerindeki farklı etkilerini araştırmıştır. Çalışmada müşteri ilişki algılarının üç boyutu (duygusal bağlılık, memnuniyet ve ödeme eşitliği) ve ilişkisel pazarlama araçları (sadakat programları ve doğrudan postalar) test edilmiştir. Sonuçlar ekonomik teşvikleri sağlayan sadakat programları ve duygusal bağlllığın hem müşteriyi elde tutma hem de müşteri payı gelişimini olumlu yönde etkilerken, doğrudan postaların sadece müşteri payı gelişimini etkilediğini göstermiştir. Ahadmotlaghi ve Pawar (2012) Hindistan havayolları şirketlerinde 900 yolcu üzerinde yaptıkları araştırmanın bulgularına göre Mì'in yolcuların yüksek sadakatini sağladığını ve yolcuların şirket müşteriliğinden vazgeçmesine karşı bir bariyer oluşturduğunu ifade etmişlerdir. Hizmetlerin kişiselleştirilmesi, havayolu şirketi tarafından gösterilen iletişimsel çabalar, müşterilerin havayolu şirketine güvenmesi, şirketin sözlerini tutması ve daha iyi kaliteli hizmetlerin sunulmasının müşteri memnuniyeti ve sadakatini etkileyen ana faktörler olduğunu ortaya çıkarmıştır.

\section{Metodoloji}

\section{1. Çalışmanın Konusu ve Amacı}

Çalışmanın konusu, havayolu müşterilerinin algıladıkları müşteri ilişkileri uygulamalarının onların ilişki kalitesi yorumları ve sonrasında da sadakatleri üzerindeki etkisi çerçevesinde sınırlı kalacaktır. Günümüzde teknoloji alanında gerçekleşen hızlı gelişmeler ve artan rekabet baskısı, hizmet sektöründe ve özellikle havayolu taşımacılığı bağlamında kendini göstermiş ve bireyin satın alma sürecinde etkili olan her faktörün, dolayısıyla da müşteri ilişkileri yönetiminin buna göre yeniden düzenlenmesini bir zorunluluk haline getirmiştir. Bu kapsamda elektronik müşteri ilişkileri uygulamaları yardımıyla müşterinin elde tutulması ve satışların artıılması mümkün gözükmektedir. Bu paralelde yapılan çalışmada havayolu taşımacılığı elektronik ticaret müşterilerinin kullandıkları sistemden ve bu sistem yardımıyla sunulan müşteri ilişkilerinden tatminlerini ve sisteme devam etme niyetlerini etkileyen ilişki faktörleri ile müşteri sadakatleri incelenmiş ve bu faktörler arasındaki ilişkiler ampirik olarak ortaya konulması amaçlanmıştır. Ayrıca, ilişki kalitesinin müşteri ilişkileri uygulanmaları ile müşteri sadakati değişkenleri arasındaki aracılık etkisi olup olmadığının tespit edilmesi de amaçlanmıştır.

\subsection{Varsayımlar, Kapsam ve Sinırlılıklar}

Çalışma çerçevesinde hazırlanacak anket formunun Demografik Verilerin, Elektronik Müşteri İlişkileri Uygulamalarının, Algılanan Müşteri İlişkileri Kalitesinin ve Müşteri Sadakatinin üzerindeki etkilerini doğru ve geçerli şekilde tespit edeceği, katılımcıların anket formunu gerçekçi ve dürüst bir şekilde cevaplayacakları ve seçilecek örneklemin evreni yansıtacağı varsayımları altında gerçekleştirilmiştir. Araştırmanın kapsamını, çalışmanın amacına uygun şekilde seçilecek örneklem üzerinde demografik verilerin, elektronik müşteri ilişkileri yönetimi uygulamalarının, algılanan ilişki kalitesinin ve müşteri sadakatinin ve bu değişkenler arasındaki ilişkilerin araştırılması oluşturmaktadır. Bu çalışma, araştırmanın gerçekleştirileceği üniversitenin Sosyal Bilimler Enstitüsünün işletme, insan kaynakları ve yönetim organizasyon bölümü ile Bilişim Enstitüsünün yönetim bilişim sistemleri ve bilişim sistemleri programları öğrencileri ile sınırlıdır. Araştırma Ekim-2017 ve Temmuz 2018 tarihleri Arasında gerçekleştirilmiştir. Dolayısıyla araştırma bu dönemler içindeki öğrenci sayıları ve buna bağlı olarak toplanan verilerle sınırlıdır. İlgili dönemde bu programlara toplam kayıtlı öğrenci sayısı 629'dur. Tam sayım hedeflenmiş, bununla birlikte derse devam etmeyen ve sonrasında kayıt donduran öğrenciler nedeniyle 479 katılımcıya ulaşılmıştır. Bu kapsamda ulaşılan örneklemin evrenin yaklaşık \% 76'sını temsil ettiği ifade edilebilir.

\subsection{Veri Toplama Tekniği ve Aracı}

Araştırmanın veri toplama tekniği anket yöntemidir. Konu ile ilgili gerçekleştirilen önceki çalışmalar göz önünde bulundurularak ve gerekli literatür taraması yapılarak hazırlanan anket formu öğrencilere elden dağıtılarak ve/veya e-posta yoluyla, ayrıca ilgili enstitülerin web sayfalarından öğrencileri yönlendirerek uygulanmıştır. Anket formu dört bölümden oluşmuştur. Bunlar; demografik faktörler, algılanan elektronik müşteri ilişkileri yönetimi uygulamaları (algılanan ödüller ve ayrıcalıklı işlem), algılanan ilişki kalitesi ve müşteri sadakatidir. Elde edilen veriler başta geçerlilik ve güvenilirlik, sonrasında korelasyon, regresyon, varyans ve de yapısal eşitlik modeli ile değerlendirilmiş ve gerekli analizler gerçekleştirildikten sonra elde edilen sonuçlar yorumlanmıştır. Bu çalışmada kullanılan ölçekler konu ile alakalı önceki çalışmalar titizlikle incelendikten sonra uygun ölçeğin uyarlanmasıyla hazırlanmıştır. Bu çalışmada Lam, Cheung ve Lau (2013) 


\section{A. Sökmen - M. Baş 11/1 (2019) 641-652}

tarafından uyarlanan ve 11 madde dört boyuttan (algılanan ödüller, ayrıcalıklı işlem, kişilerarası iletişim ve doğrudan posta) oluşan E-MİY uygulamaları ölçeğinin algılanan ödüller (3 madde) ve ayrıcalıklı işlem (3 madde) boyutları ele alınmıştır. Yine aynı yazarlar tarafından geliştirilen 3 maddeden oluşan "algılanan ilişki kalitesi" ölçeği ve 3 maddeden oluşan "müşteri sadakati" ölçeği kullanılmıştır. Çeviri ve ters çeviri yapılırken alan uzmanlarından gerekli destek sağlanmış, ayrıca pilot uygulama da gerçekleştirilmiştir. Cevaplar 5'li Likert ölçeği ile alınmıştır (1=Kesinlikle Katılmıyorum, 5=Kesinlikle Katılıyorum şeklinde).

\subsection{Araştırmanın Modeli ve Hipotezleri}

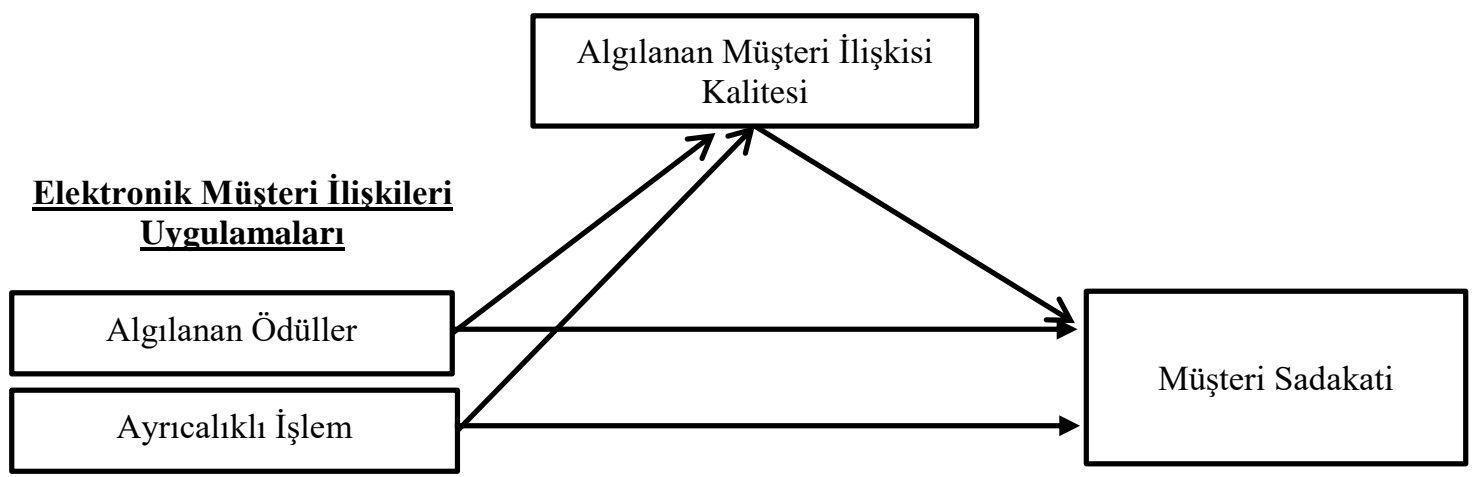

Şekil 1. Araştırmanın Modeli

Hipotez 1= Algılanan ödüller, müşteri sadakatini anlaml ve pozitif olarak etkilemektedir.

Hipotez 2= Ayrıcalıkl işlem, müşteri sadakatini anlamlı ve pozitif olarak etkilemektedir.

Hipotez 3= Alg̨lanan ödüller, algılanan müşteri ilişkileri kalitesini anlamlı ve pozitif olarak etkilemektedir.

Hipotez 4= Ayrıcalıklı işlem, algılanan müşteri ilişkileri kalitesini anlamlı ve pozitif olarak etkilemektedir.

Hipotez $\mathbf{5}=$ Algılanan müşteri ilişkileri kalitesi, algılanan müşteri sadakatini anlamlı ve pozitif olarak etkilemektedir.

Hipotez 6= Algılanan ödüllerin müşteri sadakatine etkisinde algılanan müşteri ilişkileri kalitesinin aracıllk rolü vardır.

Hipotez 7= Ayrıcalıkh işlemin müşteri sadakatine etkisinde alg̨lanan müşteri ilişkileri kalitesinin aracıllk rolü vardır.

Aşağıdaki Tablo 1'de görüldüğü üzere toplam 479 katılımcının \%54,3'ünün erkek, \%45,7'si ise kadındır. Toplam katılımcıların büyük bir çoğunluğu 26-33 (\%57,2) yaş arasındadır. Bunu \%17,32 ile 34-41 yaş arasında olanlar takip etmektedir. Katılımcıların \% 50,5'i evli, \% 49,5'i ise bekârdır. Katılımcılar tarafından sık olarak tercih edilen havayolu şirketleri incelendiğinde sırasıyla \%52 oranla Türk Hava Yolları, \%25,5 oranla Pegasus ve \%22,5 oranla Anadolu jet gelmektedir.

Tablo 1. Frekans Analizi

\begin{tabular}{|c|c|c|c|}
\hline & & Frekans & $(\%)$ \\
\hline \multirow{2}{*}{ Cinsiyet } & Erkek & 260 & 54,33 \\
\hline & Kadın & 219 & 45,7 \\
\hline \multirow{4}{*}{ Yaş } & $18-25$ & 62 & 12,9 \\
\hline & $26-33$ & 274 & 57,2 \\
\hline & $34-41$ & 83 & 17,3 \\
\hline & $42-49$ & 60 & 12,5 \\
\hline \multirow{2}{*}{ Medeni Durum } & Evli & 242 & 50,5 \\
\hline & Bekar & 237 & 49,5 \\
\hline \multirow{3}{*}{ Tercih Edilen Havayolu Şirketi } & Türk Hava Yolları & 249 & 52,0 \\
\hline & Anadolu Jet & 108 & 22,5 \\
\hline & Pegasus & 122 & 25,5 \\
\hline Toplam & & 479 & 100 \\
\hline
\end{tabular}




\subsection{Araştırmanın Bulguları}

\subsubsection{Korelasyon ve Güvenilirlik Analizleri}

Elektronik müşteri ilişkileri yönetimi uygulamaları (algılanan ödüller, ayrıcalıklı işlem), algılanan müşteri ilişkileri kalitesi ve müşteri sadakati ölçeklerinin iç tutarlılığı cronbach's alpha $(\alpha)$ güvenilirlik katsayısı ile ölçülmüştür. Araştırmada kullanılan ölçeklere ait cronbach's $\alpha$ değerleri Tablo 2'de parantez içlerinde yer almaktadır. Ölçeklerdeki tüm cronbach's $\alpha$ değerleri sınır değer olan 0,70 'den büyüktür ve kullanılan ölçeklerin oldukça güvenilir olduğunu göstermektedir. Ayrıca Tablo 2'de görüldügüu üzere araştırma değişkenleri arasındaki ilişkiyi incelemek amacıyla Pearson korelasyon analizi yapılmıştır. Buna göre "müşteri sadakati"nin; algılanan ödüller $(\mathrm{r}=0,33, \mathrm{p}<0.01)$, ayrıcalıklı işlem $(\mathrm{r}=0,35, \mathrm{p}<0.01)$ ve algılanan müşteri ilişkileri kalitesi $(\mathrm{r}=0,70, \mathrm{p}<0.01)$ ile anlamlı ve pozitif yönlü ilişkileri tespit edilmiştir. "Algzlanan müşteri ilişkileri kalitesi"; algılanan ödüller $(\mathrm{r}=0,42, \mathrm{p}<0.01)$ ve ayrıcalıklı işlem $(\mathrm{r}=0,42, \mathrm{p}<0.01)$ ile anlamlı ve pozitif yönlü bir ilişkiye sahiptir. Bununla birlikte elektronik müşteri ilişkileri uygulamaları boyutları (algılanan ödüller, ayrıcalıklı işlem) arasında anlamlı ve pozitif yönlü bir ilişki tespit edilmiştir.

Tablo 2. Korelasyon analizi

\begin{tabular}{lllll}
\hline Değişkenler & 1 & 2 & 3 & 4 \\
\hline 1.Algılanan Ödüller & $(0,93)$ & & & \\
\hline 2.Ayrıcalıklı Işlem & $0,55^{* *}$ & $(0,91)$ & & \\
\hline 3.Algılanan Müşteri İlişkileri Kalitesi & $0,42^{* *}$ & $0,42^{* *}$ & $(0,85)$ & \\
\hline 4.Müşteri Sadakati & $0,33^{* *}$ & $0,35^{* *}$ & $0,70^{* *}$ & $(0,89)$ \\
\hline
\end{tabular}

*Korelasyon 0.01 düzeyinde anlamlıdır. Parantez içindeki değerler Cronbach's Alpha güvenilirlik katsayılaridır.

\subsubsection{Regresyon Analizleri-Model 1}

Algılanan ödüller ile müşteri sadakati arasındaki ilişkide algılanan müşteri ilişkileri kalitesinin aracılık etkisini incelemek amacıyla Baron ve Kenny (1986)'nin önermiş olduğu dört aşamalı yaklaşım çerçevesinde çeşitli regresyon analizleri uygulanmıştır. Aşağıdaki Tablo 3'de her bir adım için yapılan basit ve çoklu regresyon analizleri sonuçları yer almaktadır.

Tablo 3. Regresyon Analizi Sonuçları - Model 1(N=479)

\begin{tabular}{|c|c|c|c|c|c|c|}
\hline & $\begin{array}{l}\text { Bağımsız } \\
\text { Değişken } \\
\end{array}$ & Bağımlı Değişken & B & S.H. & B & Model İstatistikleri \\
\hline 1.Adım & Algılanan Ödüller & Müşteri Sadakati & 290 & ,038 &, $33^{* *}$ & $\begin{array}{c}R^{2}=0,11 \\
F(1,477)=58,458 \\
p<0,001\end{array}$ \\
\hline 2.Adım & Algılanan Ödüller & $\begin{array}{l}\text { Algılanan Müşteri } \\
\text { İlişkileri Kalitesi }\end{array}$ & ,366 & ,036 & $42^{* *}$ & $\begin{array}{c}R^{2}=0,18 \\
F(1,477)=104,722 \\
p<0,001\end{array}$ \\
\hline 3.Adım & $\begin{array}{l}\text { Algilanan Müşteri } \\
\text { İlişkileri Kalitesi }\end{array}$ & Müşteri Sadakati & ,730 & ,032 &, $72^{* *}$ & $\begin{array}{c}R^{2}=0,49 \\
F(1,477)=506,392 \\
p<0,001\end{array}$ \\
\hline \multirow{2}{*}{ 4.Adım } & Algılanan Ödüller & Müşteri Sadakati & ,028 & 031 & ,03 & \multirow{2}{*}{$\begin{array}{c}R^{2}=0,51 \\
F(2,476)=253,497 \\
p<0,001\end{array}$} \\
\hline & $\begin{array}{l}\text { Algılanan Müşteri } \\
\text { İlişkileri Kalitesi }\end{array}$ & Müşteri Sadakati & ,716 & ,036 &, $70^{* *}$ & \\
\hline
\end{tabular}

Not: ${ }^{* *} p<0,001$, S.H. $=$ Standart Hata 
Tablo 3'de görüldüğü üzere, 1. adımda yapılan basit regresyon analizi sonucunda elektronik müşteri ilişkileri boyutlarından biri olan algılanan ödüllerin, müşteri sadakatini anlamlı ve pozitif olarak etkilediği tespit edilmiştir $(\beta=0,33 ; \mathrm{p}<0,001)$. Bununla birlikte, algılanan ödüllerin, müşteri sadakatinin \%11'ini açıkladığı görülmektedir $\left(\mathrm{R}^{2}=0,11\right)$. Elde edilen bu sonuca göre kurulan "algılanan ödüller, müşteri sadakatini anlaml ve pozitif olarak etkilemektedir" (Hipotez 1) hipotezi desteklenmiştir.

2. adımda yapılan basit regresyon analizi sonucunda algılanan ödüllerin, algılanan müşteri ilişkileri kalitesini anlamlı ve pozitif olarak etkilediği tespit edilmiştir $(\beta=0,42 ; \mathrm{p}<0,001)$. Bununla birlikte, algılanan ödüllerin, algılanan müşteri ilişkileri kalitesinin \%18'ini açıkladığı görülmektedir $\left(R^{2}=0,18\right)$. Elde edilen bu sonuca göre kurulan "algılanan ödüller, algılanan müşteri ilişkileri kalitesini anlamlı ve pozitif olarak etkilemektedir" (Hipotez 3) hipotezi desteklenmiştir.

3. adımda yapılan basit regresyon analizi sonucunda algılanan müşteri ilişkileri kalitesinin, müşteri sadakatini anlamlı ve pozitif olarak etkilediği tespit edilmiştir $(\beta=0,72 ; \mathrm{p}<0,001)$. Bununla birlikte, algılanan müşteri ilişkileri kalitesinin, müşteri sadakatinin \%49'unu açıkladığı görülmektedir $\left(R^{2}=0,49\right)$. Elde edilen bu sonuca göre kurulan "algılanan müşteri ilişkileri kalitesi, algılanan müşteri sadakatini anlamlı ve pozitif olarak etkilemektedir" (Hipotez 5) hipotezi desteklenmiştir.

Son olarak 4. adımda yapılan çoklu regresyon analizi ile algılanan ödüller ve algılanan müşteri ilişkileri kalitesinin birlikte müşteri sadakati üzerindeki etkileri incelendiğinde; algılanan müşteri ilişkileri kalitesinin müşteri sadakati üzerinde anlamlı ve pozitif yönlü etkisinin olduğunu $(\beta=0,70 ; p<0,001)$; ancak algılanan ödüllerin müşteri sadakati üzerinde anlamlı bir etkisinin olmadığı tespit edilmiştir $(\beta=0,03 ; p>0,05)$. Yani aracı değişken (algılanan müşteri ilişkileri kalitesi) modele eklendiğinde; bağımsız değişkenin (algılanan ödüller) bağımlı değişken (müşteri sadakati) üzerindeki etkisi $\beta=0,33(\mathrm{p}<0,001)$ değerinden $\beta=0,03 \quad(\mathrm{p}>0,05)$ değerine düşmüş ve aynı zamanda istatistiksel olarak anlamlı etkisini kaybetmiştir. Elde edilen bu bulgular algılanan ödüller ve müşteri sadakati ilişkisinde algılanan müşteri ilişkileri kalitesinin tam aracılık etkisinin olduğunu göstermektedir. Bununla birlikte Sobel testinin $(\mathrm{z}=10.357, \mathrm{p}<0.001)$ uygulanarak aracllık etkisinin anlamlı olduğu tespit edilmiştir. Elde edilen bu sonuca göre kurulan "algılanan ödüllerin müşteri sadakatine etkisinde algılanan müşteri ilişkileri kalitesinin aracılık rolü vardır" (Hipotez 6) hipotezi desteklenmiştir.

\subsubsection{Regresyon Analizleri-Model 2}

Ayrıcalıklı işlem ile müşteri sadakati arasındaki ilişkide algılanan müşteri ilişkileri kalitesinin aracılık etkisini incelemek amacıyla Baron ve Kenny (1986)'nin önermiş olduğu dört aşamalı yaklaşım çerçevesinde çeşitli regresyon analizleri uygulanmıştır. Aşağıdaki Tablo 4'de her bir adım için yapılan basit ve çoklu regresyon analizleri sonuçları yer almaktadır.

Tablo 4. Regresyon Analizi Sonuçları - Model 2 (N=479)

\begin{tabular}{|c|c|c|c|c|c|c|}
\hline & $\begin{array}{l}\text { Bağımsız } \\
\text { Değişken }\end{array}$ & Bağımlı Değişken & B & S.H. & B & Model İstatistikleri \\
\hline 1.Adım & Ayrıcalıklı İşlem & Müşteri Sadakati & 0,279 & 0,034 & $0,35^{* *}$ & $\begin{array}{c}R^{2}=0,12 \\
F(1,477)=68,147 \\
p<0,001\end{array}$ \\
\hline 2.Adım & Ayrıcalıklı İşlem & $\begin{array}{l}\text { Algılanan Müşteri } \\
\text { İlişkileri Kalitesi }\end{array}$ & 0,328 & 0,032 & $0,41^{* *}$ & $\begin{array}{c}R^{2}=0,17 \\
F(1,477)=103,560 \\
p<0,001\end{array}$ \\
\hline 3.Adım & $\begin{array}{l}\text { Algıllanan } \\
\text { Müşteri İlişkileri } \\
\text { Kalitesi } \\
\end{array}$ & Müşteri Sadakati & 730 & ,032 &, $72^{* *}$ & $\begin{array}{c}R^{2}=0,49 \\
F(1,477)=506,392 \\
p<0,001 \\
\end{array}$ \\
\hline \multirow[b]{2}{*}{ 4.Adım } & Ayrıcalıklı İşlem & Müşteri Sadakati & 0,049 & 0,028 & 0,06 & \multirow[b]{2}{*}{$\begin{array}{c}R^{2}=0,53 \\
F(2,476)=255,823 \\
p<0,001\end{array}$} \\
\hline & $\begin{array}{l}\text { Algılanan } \\
\text { Müşteri İlişkileri } \\
\text { Kalitesi } \\
\end{array}$ & Müşteri Sadakati & 0,703 & 0,036 & $0,69^{* *}$ & \\
\hline
\end{tabular}

Not: ** $p<0,001$, S.H. $=$ Standart Hata 


\section{A. Sökmen - M. Baş 11/1 (2019) 641-652}

Tablo 4'de görüldüğü üzere, 1. adımda yapılan basit regresyon analizi sonucunda elektronik müşteri ilişkileri boyutlarından biri olan ayrıcalıklı işlemin, müşteri sadakatini anlamlı ve pozitif olarak etkilediği tespit edilmiştir $(\beta=0,35 ; \mathrm{p}<0,001)$. Bununla birlikte, ayrıcalıklı işlemin, müşteri sadakatinin $\% 12$ 'sini açıkladığ1 görülmektedir $\left(\mathrm{R}^{2}=0,12\right)$. Elde edilen bu sonuca göre kurulan "ayrıcalıklı işlem, müşteri sadakatini anlamlı ve pozitif olarak etkilemektedir" (Hipotez 2) hipotezi desteklenmiştir.

2. adımda yapılan basit regresyon analizi sonucunda ayrıcalıklı işlemin, algılanan müşteri ilişkileri kalitesini anlamlı ve pozitif olarak etkilediği tespit edilmiştir $(\beta=0,41 ; \mathrm{p}<0,001)$. Bununla birlikte, ayrıcalıklı işlemin, algılanan müşteri ilişkileri kalitesinin \%17'sini açıkladığı görülmektedir $\left(R^{2}=0,17\right)$. Elde edilen bu sonuca göre kurulan "ayrıcalıkl işlem, algılanan müşteri ilişkileri kalitesini anlaml ve pozitif olarak etkilemektedir" (Hipotez 4) hipotezi desteklenmiştir.

3. adımda yapılan basit regresyon analizi sonucunda algılanan müşteri ilişkileri kalitesinin, müşteri sadakatini anlamlı ve pozitif olarak etkilediği tespit edilmiştir $(\beta=0,72 ; \mathrm{p}<0,001)$. Bu sonuçla ilgili ayrıntılı bilgiler yukarıda Model 1'de verilmiştir.

Son olarak 4. adımda yapılan çoklu regresyon analizi ile ayrıcalıklı işlem ve algılanan müşteri ilişkileri kalitesinin birlikte müşteri sadakati üzerindeki etkileri incelendiğinde; algılanan müşteri ilişkileri kalitesinin müşteri sadakati üzerinde anlamlı ve pozitif yönlü etkisinin olduğunu $(\beta=0,69 ; \mathrm{p}<0,001)$; ancak ayrıcalıklı işlemin müşteri sadakati üzerinde anlamlı bir etkisinin olmadığı tespit edilmiştir $(\beta=0,06 ; p>0,05)$. Yani aracı değişken (algılanan müşteri ilişkileri kalitesi) modele eklendiğinde; bağımsız değişkenin (ayrıcalıklı işlem) bağımlı değişken (müşteri sadakati) üzerindeki etkisi $\beta=0,35(\mathrm{p}<0,001)$ değerinden $\beta=0,06(\mathrm{p}>0,05)$ değerine düşmüş ve aynı zamanda istatistiksel olarak anlamlı etkisini kaybetmiştir. Elde edilen bu bulgular ayrıcalıklı işlem ve müşteri sadakati ilişkisinde algılanan müşteri ilişkileri kalitesinin tam aracılık etkisinin olduğunu göstermektedir. Bununla birlikte Sobel testinin $(\mathrm{z}=11,133, \mathrm{p}<0.001)$ uygulanarak aracilik etkisinin anlamlı olduğu tespit edilmiştir. Elde edilen bu sonuca göre kurulan "ayrıcalıkl işlemin müşteri sadakatine etkisinde algılanan müşteri ilişkileri kalitesinin aracılık rolü vardır" (Hipotez 7) hipotezi desteklenmiştir.

\section{Sonuç ve Öneriler}

Günümüzde teknoloji alanında gerçekleşen hızlı gelişmeler ve artan rekabet baskısı, hizmet sektöründe ve özellikle havayolu taşımacılığı bağlamında kendini göstermiş ve bireyin satınalma sürecinde etkili olan her faktörün, dolayısıyla da müşteri ilişkileri yönetiminin buna göre yeniden düzenlenmesini bir zorunluluk haline getirmiştir. Bu kapsamda elektronik müşteri ilişkileri uygulamaları yardımıyla müşterinin elde tutulması ve satışların artırılması mümkün gözükmektedir. Bu paralelde gerçekleşen çalışmada havayolu taşımacılığı elektronik ticaret müşterilerinin kullandıkları sistemden ve bu sistem yardımıyla sunulan müşteri ilişkilerinden tatminlerini ve sisteme devam etme niyetlerini etkileyen ilişki faktörleri ile müşteri sadakatlerinin incelenmesi ve bu faktörler arasındaki ilişkilerin ampirik olarak ortaya konulması amaçlanmıştır. Ülkemizde müşteri ilişkileri yönetimine yönelik çalışmalar olmasına rağmen elektronik müşteri ilişkileri yönetimi konusundaki incelemeler kısıtlıdır. İncelememize göre literatürde, özellikle de havayolu sektöründe bu değişkenler arasındaki ilişkilerin daha önce incelenmemiş olması, bu tez çalışmasını daha da özgün kılmaktadır.

$\mathrm{Bu}$ çalışmada belirlenen amaç doğrultusunda, E-MiY'in ayrıcalıklı işlem ve ödül uygulamalarının müşterilerle olan ilişki kalitesi ile ve müşteri sadakatine olan etkisi incelenmiş, ilişki kalitesinin ilgili uygulamalar ile müşteri sadakatine olan etkisinde aracilık rolü tespit edilmeye çalışılmıştır. Elde edilen verilere uygun analizlerin gerçekleştirilmesiyle ulaşılan sonuçlara göre; algılanan ödüllerin ve ayrıcalıklı işlemlerin müşteri sadakatini ve ilişki kalitesini anlamlı ve pozitif olarak etkilediği tespit edilmiştir ve böylece $\mathrm{H}_{1}, \mathrm{H}_{2}, \mathrm{H}_{3}$ veH 4 kabul edilmiştir. Tüm bu sonuçlar, sırasıyla en çok tercih edilen THY, Pegasus ve Anadolu Jet havayolu şirketlerinin müşterilerine çeşitli ödüller ve bazı ayrıcalıklı işlemler tanıması müşterilerin daha iyi bir ilişki kalitesi algısına sahip olmalarını sağladığını göstermektedir. Bu şirketler tarafından sunulan ödüller satış indirimi, promosyon, bedava bilet farklı sektörlerden işletmeler ile yapılan müşteriye özel yapılan indirim anlaşmaları vb. olarak tercih edilmektedir. THY'nin Miles\&Smiles kredi kartına sahip yolcularına özel rezervasyon önceliği, kredi kartı üyelik statüsüne göre değişen ek bagaj hakkı, Business Class kontuarını kullanarak sıra beklemeden check-in yapma imkânı, lounge hizmetlerini kullanma hakk1; Pegasus'un BolBol\&Rocket Miles uygulamasıyla konaklamalardan ve araç kiralamalarından kazanılan puanların uçak bileti alımlarında kullanılması; Anadolu Jet'in müşterilerine özel araç 


\section{A. Sökmen - M. Baş 11/1 (2019) 641-652}

kiralamalarında sunduğu indirim, havayolu transferi hizmeti kampanyaları gibi uygulamalar ise bu havayolu şirketlerinin sadece müşterilerine özel sundukları ayrıcalıklı işlemlerdendir. Bu tür ayrıcalıklı işlemlerin şirketlerinin müşterileri ile olan ilişki kalitesine pozitif yönde etki ettiği ifade edilebilir. Diğer taraftan algılanan müşteri ilişki kalitesinin, müşteri sadakatini pozitif yönde ve kuvvetli derecede etkilediği ve ayrıcalıklı işlem ve algılanan ödüllerin müşteri sadakatine olan etkisinde tam aracı role sahip sonucuna ulaşılmıştır ve $\mathrm{H}_{5}, \mathrm{H}_{6}$ ve $\mathrm{H}_{7}$ de kabul edilmiştir. Bu sonuçlar göstermektedir ki müşterilere özel yapılan ödüllendirmeler ve ayrıcalıklı işlemler onlarda müşteri sadakati oluşturmada etkili yöntemlerdendir. Bu yüzden bu uygulamaların çeşitliliği ve sürekliliği müşteri çekme ve tutundurmada büyük önem arz etmektedir. Öte yandan kolay üyelik imkânları, her bütçeye uygun çeşitli uygulamaların sunulması ve bu uygulamalar ile ilgili detaylı bilgilendirmeler ve ilgi çekici sıklıkla yapılan reklamlar yeni müşterilerin kazanılmasını, işletmeye bağlı sadık müşterilerin oluşmasını kolaylaştıracaktır. Sonuç olarak benzer ölçeklerin kullanımıyla farklı sektörlerde, daha büyük ve farklı özelliklere sahip örneklemlerde yapılacak konu ile ilgili çalışmaların literatüre katkı sağlayacağı ve işletmelere farklı bakış açıları kazandırabileceği düşünülmektedir.

\section{Kaynakça}

Adabanjo, D. (2003). Classifying and Selecting e-CRM Applications: An Analysis-based Proposal, Management Decision, 6(4), 570-577.

Ahadmotlaghi, E., and Pawar, P. (2012). Analysis of CRM programs practiced by passengers' airline industry of India and its impact on customer satisfaction and loyalty, Journal of Arts, Science and Commerce, 3(2), 119-127.

Baron, R. M., \& Kenny, D. A. (1986). The moderator-mediator variable distinction in social psychological research: Conceptual, strategic, and statistical considerations. Journal of personality and social psychology, 51(6), 1173.

Bowen, J. T. and Chen, S. (2001). The Relationship Between Customer Loyalty and Customer Satisfaction, International Journal of Contemporary Hospitality Management, (13-5), 213-217.

Čater, T., and Čater, B. (2010). Product and relationship quality influence on customer commitment and loyalty in B2B manufacturing relationships, Industrial Marketing Management, 39(8), 1321-1333.

Chao, P. (2008). Exploring the Nature of The Relationships Between Service Quality and Customer Loyalty: An Attribute-Level Analysis, The Service Industries Journal, 28(1), 95-116.

Chen, Y.C., Shen, Y.C. and Liao, S.(2009). An integrated model of customer loyalty: an empirical examination in retailing practice, The Service Industries Journal, 29(3), 267-280

Cheng, S.I. (2011). Comparisons of competing models between attitudinal loyalty and behavioral loyalty, International Journal of Business and Social Science, 2(10), 149-166.

Chung, K. H., and Shin, J. I. (2010). The Antecedents and Consequents Of Relationship Quality İn İnternet Shopping. Asia Pacific Journal Of Marketing and Logistics, 22(4), 473-491.

Deming, W.E.(1996). Krizden Çıkış (Çeviren: Cem Akaş). İstanbul: Arçelik ve Kalite Derneği.

Dick, S.A. and Basu, K. (1994). Customer Loyalty; Toward An Integrated Conceptual Framework, Journal of The Academy of Marketing Science, (22-2), 99-113.

Dökmen, Ü. (1994). İletişim Çatışmaları ve Empati, İstanbul: Sistem Yayıncılık.

Dwyer, F. R., Schurr, P. H., and Oh, S. (1987). Developing buyer-seller relationships, Journal of Marketing, 51(2) 11-27.

Fairhurst, P. (2001). e-CRM, Journal of Database Marketing, 2(8), 137-142.

Feinberg, R.A., R. Kadam, L. Hokama, and I. Kim. (2002). The State of Electronic Customer Relationship Management in Retailing, International Journal of Retail and Distribution Management, 30(10), 470481. 


\section{A. Sökmen - M. Baş 11/1 (2019) 641-652}

Fleischer, J.(2001). Changing the fabric of customer service, Call Center Magazine, pp.24-38.

Grönroos, C. (2000). Creating a relationship dialogue: communication, interaction and value, The Marketing Review, 1(1), 5-14.

Gundlach, G. T., Achrol, R. S., and Mentzer, J. T. (1995). The structure of commitment in exchange, Journal of Marketing, 59(1), 78-92.

Hendricks, K.B., Singhal, V.R. and Stratman, J. (2007). The impact of enterprise systems on corporate performance: a study of ERP, SCM, and CRM system implementations, Journal of Operations Management, 25(1), 65-82.

Khalifa, M., and N. Shen (2005). Effects of Electronic Customer Relationship Management on Customer Satisfaction: A Temporal Model, Proceedings of the 38th Hawaii International Conference on System Sciences, HICSS'05: 171-182, Hawaii.

King, C. A., and Garey, J. G. (1997). Relational quality in service encounters, International Journal of Hospitality Management, 16(1), 39-63.

Knox, S. D. (1998). Loyalty-Based Segmentation and The Customer Development Process, European Management Journal, 16(6), 729-737.

Lages, C., Lages, C. R., and Lages, L. F. (2005). The Relqual scale: a measure of relationship quality in export market ventures, Journal of business Research, 58(8), 1040-1048.

Lam, A. Y., Cheung, R., \& Lau, M. M. (2013). The influence of internet-based customer relationship management on customer loyalty. Contemporary Management Research, 9(4).

Levitt, T. (1986). Marketing Imagination: New. Simon and Schuster.

Macintosh, G. (2007). Customer Orientation, Relationship Quality, and Relational Benefits To The Firm. Journal Of Services Marketing, 21(3), 150-159.

Madeja, N., and D. Schoder. (2003). Impact of Electronic Commerce Customer Relationship Management on Corporate Success-Results from an Empirical Investigation, 36th Hawaii International Conference on System Sciences (HICSS-36 2003)-Abstracts Proceedings, IEEE Computer Society: 181-191, Big Island, HI.

Maged, A. and A. Sarmad (2004). Developing A Structural Approach for Electronic Customer Relationship Management (e-CRM), European \& Mediterranean Conference on Information Systems, EMCISBrunel University, Tunis.

Mandina, S.P. (2014). Contribution of CRM Strategies in Enhancing Customer Loyalty, Journal of Marketing Development and Competitiveness, 8(2), 69-87.

Morgan, R.M. and Hunt, S.D. (1994). The Commitment-Trust Theory of Relationship Marketing, Journal of Marketing, 58(3), 20-38.

Oly, N.N. (2007). Relationship quality antecedents: the Malaysian retail banking perspective, International Journal of Quality \& Reliability Management, 24(8), 829-845

Osarenkhoe, A. and Bennani, A., E. (2007). An Exploratory Study of Implementation of Customer Relationship Management Strategy, Business Process Management Journal, 13(1), 139-164

Pan, S.L., and J.N. Lee (2003). Using e-CRM for a Unified View of the Customer, Communications of the ACM, 46(4), 95-99.

Parasuraman, A., Berry, L.L. and Zeithaml, V.A. (1991). Perceived service quality as a customer-based performance measure: An empirical examination of organizational barriers using an extended service quality model. Human Resource Management, 30(3), 335-364.

Rafiq, M., Fulford, H., and Lu, X. (2013). Building Customer Loyalty İn Online Retailing: The Role Of Relationship Quality. Journal Of Marketing Management, 29(3-4), 494-517. 


\section{A. Sökmen - M. Baş 11/1 (2019) 641-652}

Ross, D.F. (2005). E-CRM From a Supply Chain Management Perspective, Journal of Information Systems Management, 1(22), 37-44.

Ryals, L. and Knox, S. (2001). Cross-functional issues in the implementation of relationship marketing through customer relationship management, European Management Journal, 19(5), 534-542.

Sivaraks P., Krairit, D., and Tang, J.C.S.(2011). Effects of e-CRM on customer-bank relationship quality and outcomes: The case of Thailand, Journal of High Technology Management Research, 22(2), 141-157.

Sprague, J.C., Gopalakrishnan, K.N., and Mcltrye, B.E. (1992). Implementing Internal Quality Improvement with the House of Quality, USA: Quality Progress.

Sterne, J. (1996). Customer service on the Internet: building relationships, increasing loyalty, and staying competitive. New York: Wiley.

Taylor, S.A., and G.L. Hunter (2002). The Impact of Loyalty with e-CRM Software and e-Services, International Journal of Service Industry Management, 5(13), 452-474.

Tucker W. T. (1964). The development of brand loyalty, Journal of Marketing Research, 1(3), 32-35.

Verhoef, P. C. (October,2003). Understanding the effect of customer relationship management efforts on customer retention and customer share development, Journal of marketing, 67(4), 30-45.

Yoon, D., S.M. Choi, and D. Sohn. (2008). Building Customer Relationships in an Electronic Age: The Role of Interactivity of e-Commerce Websites, Psychology \& Marketing, 7(25), 602-618

Zeithaml, V. A., Berry, L. L. and Parasuraman, A. (1996). The behavioral consequences of service quality, Journal of Marketing, 60(2), 31-46. 